\title{
A preliminary investigation of the relationship between water quality and Anopheles gambiae larval habitats in western Cameroon
}

\author{
Michelle R Sanford ${ }^{1}$, Steven Ramsay ${ }^{2}$, Anthony J Cornel ${ }^{2,4}$, Clare D Marsden²,3, Laura C Norris, \\ Salomon Patchoke ${ }^{5}$, Etienne Fondjo ${ }^{5}$, Gregory C Lanzaro ${ }^{2,3}$ and Yoosook Lee ${ }^{2,3^{*}}$
}

\begin{abstract}
Background: Water quality and anopheline habitat have received increasing attention due to the possibility that challenges during larval life may translate into adult susceptibility to malaria parasite infection and/or insecticide resistance.

Methods: A preliminary study of Anopheles gambiae s.s. larval habitats in the north-west and south-west regions of Cameroon was conducted in order to detect associations between An. gambiae s.s. molecular form and 2La inversion distributions with basic water quality parameters. Water quality was measured by temperature, $\mathrm{pH}$, conductivity, total dissolved solids (TDS) at seven sites in Cameroon and one site in Selinkenyi, Mali.

Results: Principal components and correlation analyses indicated a complex relationship between $2 \mathrm{La}$ polymorphism, temperature, conductivity and TDS. Cooler water sites at more inland locations yielded more $\mathrm{S}$ form larvae with higher $2 \mathrm{La}$ inversion polymorphism while warmer water sites yielded more $\mathrm{M}$ form larvae with rare observations of the 2 La inversion.

Discussion: More detailed studies that take into account the population genetics but also multiple life stages, environmental data relative to these life stages and interactions with both humans and the malaria parasite may help us to understand more about how and why this successful mosquito is able to adapt and diverge, and how it can be successfully managed.
\end{abstract}

Keywords: Conductivity, Total Dissolved Solids, Molecular Form, Anopheles Gambiae s.s

\section{Background}

As the primary vector of Plasmodium falciparum in West Africa, Anopheles gambiae s.s. is among the beststudied malaria vector species in Africa. A large literature exists from many of countries in West Africa, where population genetics [1-5] and genomics [6-11] have revealed population structure and differentiation among populations of An. gambiae s.s., including the molecular forms of $\mathrm{M}$ and S [2], and the five chromosomal forms (Mopti, Savanna, Bamako, Bissau and

\footnotetext{
* Correspondence: yoslee@ucdavis.edu

${ }^{2}$ Vector Genetics Laboratory, School of Veterinary Medicine, University of California, Davis, CA, USA

${ }^{3}$ Department of Pathology, Microbiology and Immunology, University of California, Davis, CA, USA

Full list of author information is available at the end of the article
}

Forest), which are characterized by different arrangements of a set of six paracentric inversions [12-16].

The factors underlying divergence within An. gambiae have been the subject of much interest. Despite low frequencies of molecular form hybrids and among chromosomal forms [17,18], studies suggest an absence of intrinsic post-mating reproductive isolation mechanisms $[19,20]$, indicating that pre-mating factors play a major role in the evolution and maintenance of divergence. Whilst specific mechanisms underlying divergence among chromosomal forms have not been identified, the forms have been associated with particular habitats, and thus ecologically based divergence is thought to be important $[21,22]$. In the molecular forms, considerable evidence supports the importance of a number of premating factors including mating swarm segregation [23],

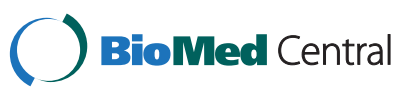


cuticular hydrocarbon differentiation [24], wing beat frequency harmonization $[25,26]$ and larval habitat segregation [27-29]. Until recently, these have been largely assumed to be universal throughout the large distribution of the species [30]. However, recent work in Guinea-Bissau, has revealed both genetic [31,32] and phenotypic [26] departures from previous assumptions. Larval habitat segregation between the molecular forms shares its foundation with the ecologically based chromosomal speciation hypothesis which suggests that differing ecological characteristics are driving divergence and adaptation among populations of An. gambiae [21,33,34]. A recent study in Burkina Faso supports this hypothesis by showing differential habitat utilization between the $M$ and $\mathrm{S}$ forms in agricultural rice fields and natural habitats $[29,35]$. In Burkina Faso, M forms are more often encountered in rice fields whereas $\mathrm{S}$ forms are more often found in naturally occurring puddles $[29,35]$.

Breaking with previous assumptions, recent work in Cameroon has shown a more complicated pattern of habitat segregation. Samples collected from developed areas of the country identified more $S$ form larvae in cultivated areas (not necessarily associated with rice) whereas $M$ form larvae were more often encountered in natural pools (both polluted and unpolluted) in the urbanized areas of Yaoundé and Douala [36]. In the southern agricultural area of Niete the $M$ form predominates [37]. One potential explanation for the differences is that the relationship between molecular forms and chromosomal forms is complicated by further population structure in Cameroon. Specifically, the Forest-M form, which is characterized by the absence of chromosome inversions, has been identified as a separate subpopulation within the $\mathrm{M}$ form $[3,38]$. Moreover, the Forest-M form has been shown to be associated with the humid evergreen forest habitat in contrast to the Mopti-M form which occurs most commonly in dry environments $[9,27]$ and carries $2 R b, c$ and $u$ inversions [34].

Consistent with research in other taxa [39-43], specific chromosomal inversions in An. gambiae have shown to be strongly correlated with ecological parameters. In Cameroon, the large inversion on the left arm of the second chromosome, $2 \mathrm{La}$, which is found in the all chromosomal forms except Forest, has been associated with desiccation resistance in adults $[44,45]$ and is often associated with populations in arid areas of West Africa. Within the S form the $2 \mathrm{La}$ inversion follows a latitudinal cline with the inversion predominating in the drier north of Cameroon and rarely occurring in the tropical south of Cameroon [46].

The goal of this study was to assess patterns of molecular form and $2 \mathrm{La}$ inversion polymorphism in north-western Cameroon with basic water quality parameters. The location of the sites in this study covers both areas where the $2 L a$ inversion is polymorphic and molecular forms are heterogeneous to explore the potential for patterns related to water quality, $2 \mathrm{La}$ inversion and molecular form.

\section{Methods \\ Collection}

Anopheline larvae were collected from characteristic aquatic habitats near human habitations at seven sites in Cameroon with an additional site from Mali included for comparative purposes (Table 1). A minimum of ten larvae were collected at each site in conjunction with the water quality parameters of temperature, conductivity, total dissolved solids (TDS), and $\mathrm{pH}$ as measured with a Hanna Instruments HI 9812-5 (Ann Arbor, MI, USA). Calibration was conducted with Hanna Instruments calibration solutions (pH: HI 7004, HI 7007, HI 7010; Conductivity: HI 70031; TDS: HI 70032) before each measurement was made. The measurements were taken at the same time of day, approximately 11:00 AM. Table 1 lists the site locations and their respective water quality measurements. Diabate and his colleagues suggested the effect of mosquito larval predators in divergence between $M$ and $S$ forms [47]. Thus we logged our observation regarding larval predators such as beetles, dragonfly nymphs or aquatic hemipterans for each sampling location. Larvae were reared to adults in the field sites when possible to facilitate sex determination as well as to differentiate predatory mosquito larvae from $A n$. gambiae. All specimens were preserved in $70 \%$ ethanol.

\section{Processing}

Each individual mosquito was processed for DNA extraction with the Qiagen (Valencia, CA, USA) Blood and Tissue kit adapted for the high-throughput Biosprint $96^{\circ}$ system with tissue disruption using a Qiagen Tissuelyzer ${ }^{\circledR}$ following the manufacturer's instructions. Species determinations were made via PCR to distinguish between members of the An. gambiae complex following Scott et al. [48]. Molecular form determinations of An. gambiae s.s. were made using the method of Favia et al. [49] followed by the method of Santolamazza et al. [50] to clarify samples that gave ambiguous results with the first PCR.

Lee et al. [3] suggested that molecular form combined with $2 \mathrm{La}$ inversion data provides good proxy for differentiating the Forest- $\mathrm{M}$ form from Mopti-M form. Thus, the $2 \mathrm{La}$ inversion status of each mosquito was determined by PCR using the method of White et al. [51]. Insertion-deletion polymorphisms were observed in the PCR fragment patterns of hetero- and homokaryotypic individuals as described by Obbard et al. [52]. Finally the sex of any larval mosquitoes remaining in the samples was determined with the PCR method of Ng'habi et al. [53]. The resulting PCR products were analysed 
Table 1 Collection site locations, date of measurement and water quality parameters of temperature (Temp.), conductivity (Cond.), total dissolved solids (TDS), pH and An. gambiae s.l. sample size (N) measured at seven sites in Cameroon and a single site in Mali

\begin{tabular}{|c|c|c|c|c|c|c|c|c|}
\hline Site & Lat. & Long. & Collection date & Temp. $\left({ }^{\circ} \mathrm{C}\right)$ & Cond. $(\mu \mathrm{S} / \mathrm{cm})$ & TDS (ppm) & $\mathrm{pH}$ & $\mathbf{N}$ \\
\hline Wasi-Ber & 6.20 & 10.67 & 28-Aug-11 & 21 & 150 & 60 & 7.1 & 11 \\
\hline Bamessing & 5.63 & 10.23 & 30-Aug-11 & 24 & 610 & 350 & 8.6 & 14 \\
\hline New Pongo & 4.12 & 9.41 & 5-Sept-11 & 28.5 & 190 & 95 & 6.9 & 15 \\
\hline Sonné & 4.10 & 9.31 & 2-Sept-11 & 28.5 & 520 & 270 & 7.3 & 81 \\
\hline Small Ikangé & 4.09 & 9.37 & 6-Sept-11 & 31 & 310 & 170 & 6.7 & 13 \\
\hline Near river outlet, Tiko & 4.07 & 9.37 & 3-Sept-11 & 35 & 300 & 150 & 8.7 & 15 \\
\hline Limbé & 4.01 & 9.19 & 4-Sept-11 & 29 & 30 & 20 & 6.2 & 22 \\
\hline Selinkenyi, Mali & 11.7 & -8.28 & 29-Sept-11 & 38 & 110 & 60 & 6.8 & 10 \\
\hline
\end{tabular}

with agarose gels specific to their respective methods or with the use of the Qiagen Qiaexcel ${ }^{\circ}$ DNA screening cartridge capillary system and the Biocalculator ${ }^{\circ}$ software using the AM420 method.

\section{Analysis}

The site GPS coordinates, water quality data, PCR results of $2 \mathrm{La}$ polymorphism and the sex of each mosquito were used to construct a principal components analysis using the Multibase2013 (NumericalDynamics.com) Excel 2010 add-in (Microsoft Inc, Redmond, WA, USA). In addition, a set of Pearson's product moment correlations were conducted among the variables of interest, using SPSS 16.0 [54]. The significance level of all statistical tests was observed at $\alpha=0.05$.

\section{Results}

All larval samples were determined to be An. gambiae s.s. Figure 1 illustrates the distribution of $\mathrm{M}$ and $\mathrm{S}$ molecular forms by site. No M/S hybrids were detected in the larval collections. The $\mathrm{S}$ form comprised the majority of collections made in cooler temperature water, while the $\mathrm{M}$ form was most commonly collected in warmer temperature habitats located near the coast (Figure 2). Molecular form (coded as 0 for $\mathrm{S}$ and 1 for $\mathrm{M}$ ) was significantly correlated with site (latitude and longitude) and temperature (Table 2), which were also correlated with each other.

Between villages, $\mathrm{pH}$ levels varied from 6.2 to 8.7 (Table 1), with the $\mathrm{M}$ form more common at the extremes of this range, while the $\mathrm{S}$ form was more common around neutral $\mathrm{pH}$ (Figure 3). Previous studies have shown subdivision within the $\mathrm{M}$ form populations in Cameroon [3,38], which raises the question of whether the $\mathrm{M}$ form collected from lower $\mathrm{pH}$ pools differed from the $\mathrm{M}$ form collected from pools of higher $\mathrm{pH}$. However, no correlations between 2La inversion polymorphism and $\mathrm{pH}$ were detected. Thus population subdivision does not appear to be a cause factor in $\mathrm{pH}$

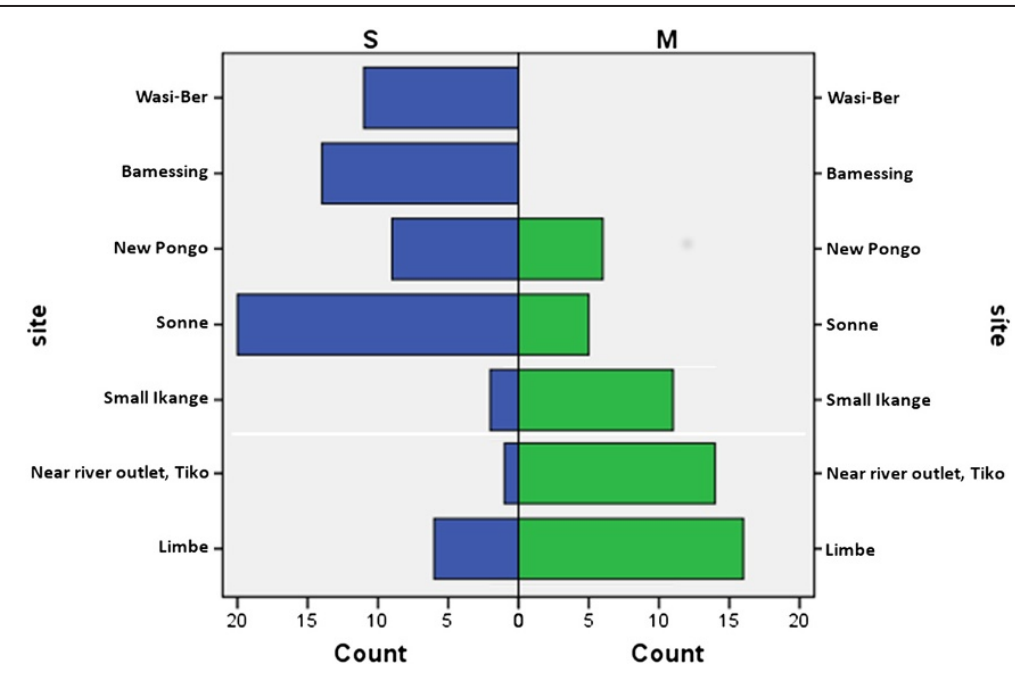

Figure 1 Molecular form distribution of larvae collected during the survey or larval habitats in north-western Cameroon in August/ September 2011. Collection site is listed by latitude in descending order. 


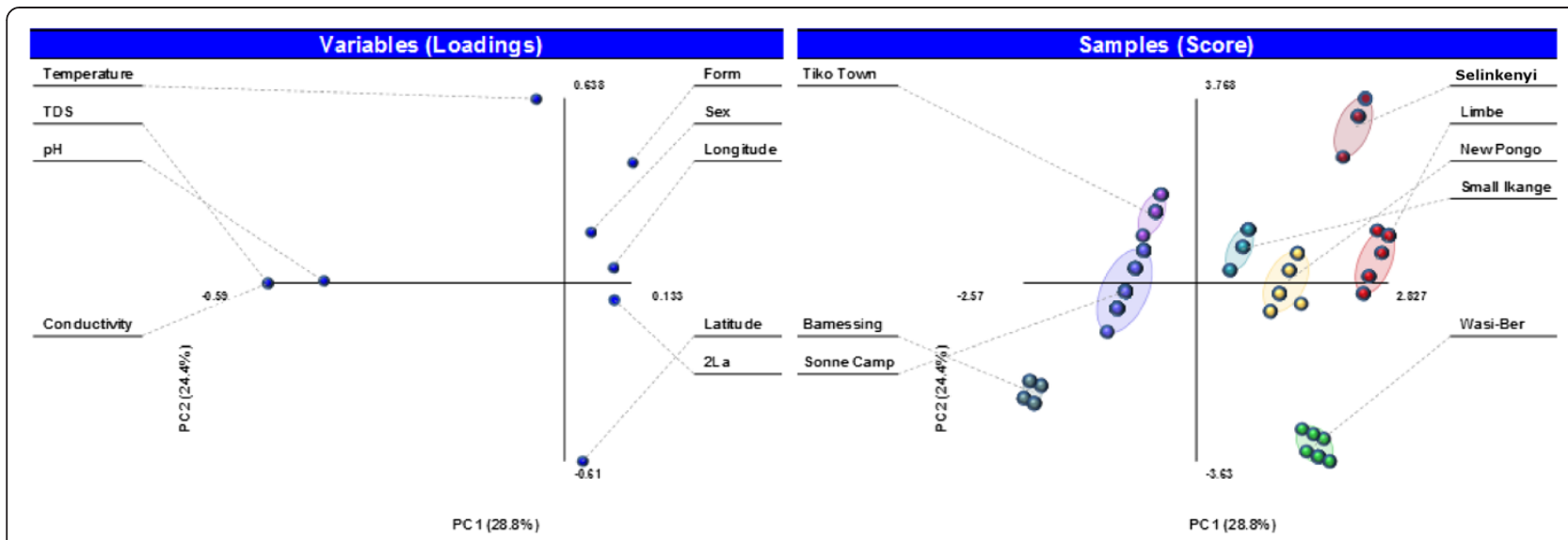

Figure 2 Principal component analysis (PCA), with variable loadings, illustrating the relationships between the variables measured in the current study investigating the relationship between water quality, $2 L a$ inversion polymorphism, sex and molecular form in north-western Cameroon.

preference of $\mathrm{M}$ form. Rather, these data suggest it may be due to the $M$ form having a better buffer resistance to $\mathrm{pH}$ changes.

The $\mathrm{S}$ molecular form was also significantly correlated with the presence of the $2 L a$ inversion while the $M$ form, collected in warmer water did not display $2 L a$ polymorphism. The interconnected nature of this relationship between these factors is illustrated in Figure 2 . While none of the samples was karyotyped for other inversions, the lack of $2 \mathrm{La}$ polymorphism in the mosquitoes near the coast strongly suggests the presence of the Forest-M chromosomal form. The relationship between the $\mathrm{M}$ form and both conductivity and TDS was also significant with a negative correlation observed between these water quality parameters and the presence of the $\mathrm{M}$ form (Table 2). All of the larvae collected from Mali were homozygous for the $2 \mathrm{La}$ inversion.

As evident in Table 1, there were relatively large gap in sampling locations between Bamessing and New
Pongo. Our collection attempt was hampered by two factors: (1) the poor condition of the roads that made travel exceedingly difficult in the rainy season and (2) the large amount of rain flushed larval habitats. We sampled several sites between Bamessing and New Pongo and failed to find larvae, presumably because the rains were flushing the habitats as fast as they were being colonized during our collection trip in late August and early September.

There were no known predatory insects observed in the pools the mosquitoes were collected from at the time of collections. No beetles, dragonfly nymphs or aquatic hemipterans were observed. However, it is possible that predatory mosquito larvae may have been present as they would have been impossible to differentiate by sight. However, no predatory mosquito larvae were collected in the reared and preserved samples. The correlation between the larval sex ratio and temperature was not statistically significant $\left(x^{2}=11.433\right.$, d.f. $\left.=6, P=0.076\right)$.

Table 2 Pearson's product moment correlations among the variables measured in the larval habitat survey conducted in north-western Cameroon

\begin{tabular}{|c|c|c|c|c|c|c|c|c|c|}
\hline & Longitude & Latitude & Temp. & $\mathrm{pH}$ & Cond. & TDS & Form & $2 L a$ & Sex \\
\hline Long. & 1.000 & $<0.001$ & $<0.001$ & $<0.001$ & 0.036 & 0.032 & $<0.001$ & $<0.001$ & 0.005 \\
\hline Lat. & $0.993^{* *}$ & 1.000 & $<0.001$ & $<0.001$ & 0.036 & 0.039 & $<0.001$ & $<0.001$ & 0.004 \\
\hline Temp. & $-0.817^{* *}$ & $-0.779^{* *}$ & 1.000 & 0.266 & 0.124 & 0.107 & $<0.001$ & $<0.001$ & 0.074 \\
\hline $\mathrm{pH}$ & $0.331^{* *}$ & $0.361^{* *}$ & 0.104 & 1.000 & $<0.001$ & $<0.001$ & 0.162 & 0.217 & 0.018 \\
\hline Cond. & $0.196^{*}$ & $0.195^{*}$ & -0.144 & $0.655^{* *}$ & 1.000 & $<0.001$ & $<0.001$ & 0.980 & 0.180 \\
\hline TDS & $0.200^{*}$ & $0.193^{*}$ & -0.151 & $0.646^{* *}$ & $0.995^{* *}$ & 1.000 & $<0.001$ & 0.964 & 0.217 \\
\hline Form & $-0.484^{* *}$ & $-0.467^{* *}$ & $0.612^{* *}$ & -0.131 & $-0.359^{* *}$ & $-0.349^{* *}$ & 1.000 & 0.001 & 0.128 \\
\hline $2 L a$ & $0.654^{* *}$ & $0.655^{* *}$ & $-0.555^{* *}$ & 0.117 & -0.002 & -0.004 & $-0.320^{* *}$ & 1.000 & 0.094 \\
\hline Sex & $-0.257^{* *}$ & $-0.263^{* *}$ & 0.167 & $-0.220^{*}$ & -0.126 & -0.116 & 0.143 & -0.158 & 1.000 \\
\hline
\end{tabular}

Upper triangle matric indicates P-values and lower triangle matric indicate Pearson Correlation. Temp. stands for Temperature and Cond. for conductivity.

**. Correlation is significant at the 0.01 level (2-tailed).

*. Correlation is significant at the 0.05 level (2-tailed). 


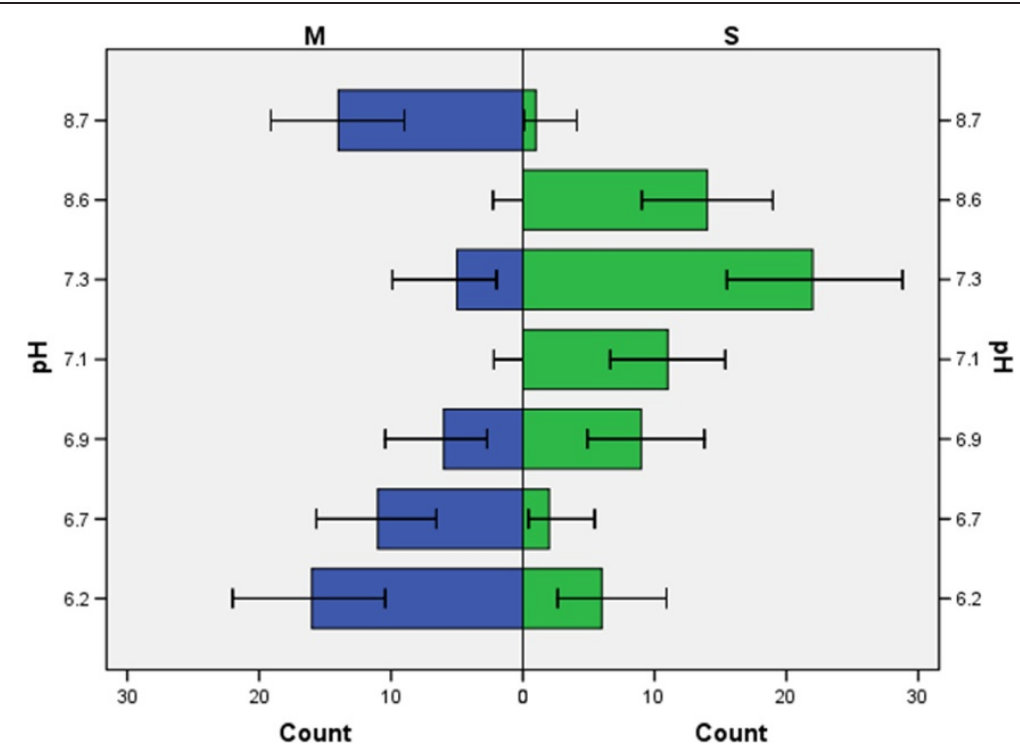

Figure 3 Distribution of individuals of each molecular form by water $\mathrm{pH}$ in north-western Cameroon. Bars indicate $95 \%$ confidence intervals.

\section{Discussion}

In this small study of larval An. gambiae habitats in north-western Cameroon, several water quality parameters were found to be significantly correlated with molecular forms. Male and female An. gambiae s. s. of the $\mathrm{M}$ and $\mathrm{S}$ molecular forms with a range of $2 \mathrm{La}$ inversion polymorphism, were collected from typical larval habitats near human dwellings. The $\mathrm{S}$ molecular form was collected in cooler water with higher conductivity and TDS and was characterized by variation in the $2 L a$ inversion. The $\mathrm{M}$ molecular form was collected in warmer water with lower conductivity and TDS and was characterized by the rarity of the $2 L a$ inversion. These findings are consistent with niche differentiation, and suggest the important role of water temperature in habitat preference.

The strong correlation observed between conductivity and TDS in the current study is similar to the result obtained by Edillo et al. [28] for young larvae collected in Banambani, Mali. They found that conductivity and TDS of larval habitat had significant effects on the relative proportions of $\mathrm{M}$ and $\mathrm{S}$ form larvae. Both the $\mathrm{M}$ and $\mathrm{S}$ forms in Mali are polymorphic but nearly fixed for the $2 \mathrm{La}$ inversion [55]. In the study presented here, those larvae polymorphic for the $2 \mathrm{La}$ inversion were also associated with higher conductivity and TDS. As Edillo et al. [28] point out, conductivity and TDS are related to each other and are in fact proportionally related and affected by temperature [56]. Thus, the significant correlations observed in the present study between temperature, conductivity and TDS in relation to molecular form might reflect adaptation to a specific combination of interrelated larval habitat characteristics. More widespread sampling among sites to establish site variation would help to establish characteristics of larval habitats and $A n$. gambiae molecular forms in this part of Cameroon.

The relationship between environmental temperature and $\mathrm{M}$ and $\mathrm{S}$ distribution has been correlated with adult An. gambiae s.s. in Cameroon. Simard et al. [57] found significant correlations between air temperature and $\mathrm{M}$ and $\mathrm{S}$ distribution among other environmental variables in Cameroon. In the current study, the temperature of the larval habitat was significantly correlated with $M$ and $\mathrm{S}$ form larvae. Data collected in Burkina Faso have also suggested a strong correlation between $\mathrm{M}$ and $\mathrm{S}$ form larval habitat segregation and larval habitat characteristics [29]. Strong correlations were found between rice agriculture and $M$ form mosquitoes. The relationship between water temperature of the larval habitat and air temperature often collected with climatic variables is not necessarily linear. In Kenya, Paaijamans et al. [58] found that water temperature of artificial mosquito larval habitats was consistently higher than air temperature. Therefore correlating temperatures with form distribution is complicated by the effect of temperature on the different life stages and its relationship to other environmental factors that also have differential effects on life stage (e.g., humidity).

The effect of temperature as it relates to sex ratio was investigated in laboratory rearing of An. gambiae and Anopheles arabiensis in mixed and monocultures [59]. As temperatures increased from 25 to $35^{\circ} \mathrm{C}$ the ratio of females to males decreased. Observed in the current study, however, did not show significant correlation with sex ratio and temperature. The current study differs in that it represents a single time point in the lives of fieldcollected mosquitoes from fluctuating natural tempera- 
ture regimes rather than constant temperature rearing as in the laboratory rearing study. Fluctuating rearing temperatures affect sex ratios at higher temperatures in Aedes aegypti [60]. However, more detailed field measurements of temperature with respect to life stage will allow for better understanding of how and at what age temperature affects sex and survival.

Previous studies in Cameroon have noted strong north-south clinal variation in the $2 L a$ inversion that follows an environmental moisture gradient that runs from the moist south to arid north [46]. In addition, polymorphism in various chromosomal inversions was correlated with the $\mathrm{S}$ form along a similar north-south cline [57]. Simard et al. [57] also found less inversion polymorphism in the $M$ form. Despite the small scale of the current study, a similar result was observed with more polymorphism in the $2 L a$ inversion noted in the $S$ form and less in the $\mathrm{M}$ form. The current study also supports the proposed habitat suitability maps created by Simard et al. [57] for Cameroon, where more $M$ forms were collected near the Atlantic coast than in the more inland and northern areas.

Although not karyotyped for inversions on $2 \mathrm{R}$, the lack of $2 \mathrm{La}$ polymorphism and an abundance of $\mathrm{M}$ form near the Atlantic coast of Cameroon suggest the presence of the Forest-M form. Lee et al. [3] also found many Forest$M$ form samples in the same areas sampled in the current study and provided evidence suggesting the $2 \mathrm{La}$ inversion and molecular form provides a good proxy for Forest-M form in southern Cameroon in the absence of karyotype data. The population subdivision within the $M$ form combined with the limited scale of the current study $[3,38]$ complicates the interpretation of the findings presented here. Specifically, since the majority of $M$ form samples also did not possess the $2 L a$ inversion one cannot rule out the possibility that the water quality factors correlated with the $M$ form were related specifically to the Forest- $M$ form, and are not representative of $M$ form in general in Cameroon. The lower number of samples collected from sites where the $2 \mathrm{La}$ inversion is more polymorphic were not sufficient to overcome this confounding factor. A larger scale sampling effort would help to address the confounding nature of the Forest- $\mathrm{M}$ form.

Water quality and anopheline habitat have also received increasing attention due to the possibility that stress during larval life may translate into adult susceptibility to malaria parasite infection [61] and/or insecticide resistance [36]. Okech et al. [61] showed that the presence of bacteria in the larval habitat resulted in more pupation and slightly larger individual An. gambiae than those reared in sterile substrate, strongly suggesting a role for microbes in larval habitats [61]. Autoclaving and killing off bacteria did not appear to affect infection rate in adults exposed to Plasmodium falciparum. However, soil type had a small effect, suggesting that larval habitat affects malaria infection susceptibility. The influence of pollution and agricultural impact on larval habitat has been suggested to have a strong effect on insecticide resistance in the agricultural areas of southern Cameroon [36]. In a detailed study of $M$ and $S$ larval habitats near Yaoundé, Cameroon, Kamdem et al. [62] found that the $\mathrm{M}$ form is becoming increasingly capable of survival in polluted habitats.

Taking into consideration the complicated nature of the various mechanisms driving population divergence in An. gambiae in Cameroon, understanding the ecological source of population divergence and mosquito control continues to be a challenge. More detailed studies that take into account the population genetics, multiple life stages, environmental data, and interactions with both humans and the malaria parasite may help us to understand more about how and why this mosquito has successfully adapted and diverged, and how it can be successfully managed.

\section{Competing interests}

The authors declare that they have no competing interests.

\section{Authors' contributions}

MRS, AJC, SP carried out field collection of mosquito specimens. GCL and EF provided logistical support for field collection and molecular genetic studies. SR conducted the molecular genetic studies. MRS, CDM, LCN, GCL and YL drafted the manuscript. MRS participated in the design of the study and performed the statistical analysis. All authors read and approved the final manuscript.

\section{Acknowledgements}

The authors wish to acknowledge the help of the staff of the Kumbo Health District and the Tiko Health Districts for their assistance in mosquito collections. This study was supported with funds from the National Institutes of Health grant \#5R01Al078183 and T32Al074550.

\section{Author details}

${ }^{1}$ Harris County Institute of Forensic Sciences, Houston, TX, USA. ${ }^{2}$ Vector Genetics Laboratory, School of Veterinary Medicine, University of California, Davis, CA, USA. ${ }^{3}$ Department of Pathology, Microbiology and Immunology, University of California, Davis, CA, USA. ${ }^{4}$ Department of Entomology and Nematology, University of California, Davis, CA, USA. ${ }^{5}$ Ministry of Public Health, Yaoundé, Cameroon.

Received: 10 May 2013 Accepted: 24 June 2013

Published: 2 July 2013

\section{References}

1. Lanzaro GC, Toure YT, Carnahan J, Zheng L, Dolo G, Traore S, Petrarca V Vernick KD, Taylor CE: Complexities in the genetic structure of Anopheles gambiae populations in west Africa as revealed by microsatellite DNA analysis. Proc Natl Acad Sci U S A 1998, 95:14260-14265.

2. DellaTorre A, Fanello C, Akogbeto M, Dossou-yovo J, Favia G, Petrarca V, Coluzzi M: Molecular evidence of incipient speciation within Anopheles gambiae s.s. in West Africa. Insect Mol Biol 2001, 10:9-18.

3. Lee $Y$, Cornel AJ, Meneses CR, Fofana A, Andrianarivo AG, McAbee RD, Fondjo E, Traore SF, Lanzaro GC: Ecological and genetic relationships of the Forest-M form among chromosomal and molecular forms of the malaria vector Anopheles gambiae sensu stricto. Malar J 2009, 8:75.

4. Marsden CD, Cornel AJ, Lee Y, Sanford MR, Goodell PB, Nieman CC, Han S, Rodrigues A, Denis J, Ouledi A, Lanzaro GC: An analysis of two island groups as potential sites for trials of transgenic mosquitoes for malaria control. Evol Appl 2012, 6(2):706-720. 
5. Riehle MM, Guelbeogo WM, Gneme A, Eiglmeier K, Holm I, Bischoff E, Garnier T, Snyder GM, Li X, Markianos K, et al: A cryptic subgroup of Anopheles gambiae is highly susceptible to human malaria parasites. Science 2011, 331:596-598.

6. Neafsey DE, Lawniczak MK, Park DJ, Redmond SN, Coulibaly MB, Traore SF, Sagnon N, Costantini C, Johnson C, Wiegand RC, et al: SNP genotyping defines complex gene-flow boundaries among African malaria vector mosquitoes. Science 2010, 330:514-517.

7. Turner TL, Hahn MW, Nuzhdin SV: Genomic islands of speciation in Anopheles gambiae. PLoS Biol 2005, 3:e285.

8. White BJ, Cheng C, Simard F, Costantini C, Besansky NJ: Genetic association of physically unlinked islands of genomic divergence in incipient species of Anopheles gambiae. Mol Ecol 2010, 19:925-939.

9. Lee Y, Collier TC, Sanford MR, Marsden CD, Fofana A, Cornel AJ, Lanzaro GC: Chromosome inversions, genomic differentiation and speciation in the African malaria mosquito Anopheles gambiae. PLoS One 2013, 8:e57887.

10. Weetman D, Wilding CS, Steen K, Pinto J, Donnelly MJ: Gene flowdependent genomic divergence between Anopheles gambiae $\mathrm{M}$ and $\mathrm{S}$ forms. Mol Biol Evol 2012, 29:279-291.

11. Reidenbach KR, Neafsey DE, Costantini C, Sagnon N, Simard F, Ragland GJ, Egan SP, Feder JL, Muskavitch MAT, Besansky NJ: Patterns of genomic differentiation between ecologically differentiated $M$ and $S$ forms of Anopheles gambiae in West and Central Africa. Genome Biol Evol 2012, 4:1202-1212.

12. White GB: Anopheles bwambae Sp-N, a malaria vector in the Semliki Valley, Uganda, and its relationships with other sibling species of the An. gambiae complex (Diptera, Culicidae). Systematic Entomology 1985, 10:501-522.

13. Hunt RH, Coetzee M, Fettene M: The Anopheles gambiae complex: a new species from Ethiopia. Trans R Soc Trop Med Hyg 1998, 92:231-235.

14. Mosquito Taxonomic Inventory. http://mosquito-taxonomic-inventory.info/ sites/mosquito-taxonomic-inventory.info/files/Anopheles\%20classifica tion_25.pdf.

15. Coetzee M, Hunt RH, Wilkerson RC, DellaTorre A, Coulibaly MB, Besansky NJ: Anopheles coluzzii and Anopheles amharicus, new members of the Anopheles gambiae complex. Zootaxa 2013, 3619:246-274.

16. Davidson G, Hunt RH: The crossing and chromosome characteristics of a new, sixth species in the Anopheles gambiae complex. Parassitologia 1973, 15:121-128

17. DellaTorre A, Tu Z, Petrarca V: On the distribution and genetic differentiation of Anopheles gambiae s.s. molecular forms. Insect Biochem Mol Biol 2005, 35:755-769.

18. Taylor C, Touré YT, Carnahan J, Norris DE, Dolo G, Traoré SF, Edillo FE, GC L: Gene flow among populations of the malaria vector, Anopheles gambiae, in Mali, West Africa. Genetics 2001, 157:743-750

19. Diabate A, Dabire RK, Millogo N, Lehmann T: Evaluating the effect of postmating isolation between molecular forms of Anopheles gambiae (Diptera: Culicidae). J Med Entomol 2007, 44:60-64.

20. Persiani A, Di Deco MA, Petrangeli G: [Laboratory observation of inversion polymorphisms originating from the crossing of various populations of Anopheles gambiae s.s](in Italian). Ann Ist Super Sanita 1986, 22:221-223.

21. Manoukis NC, Powell JR, Toure MB, Sacko A, Edillo FE, Coulibaly MB, Traore SF, Taylor CE, Besansky NJ: A test of the chromosomal theory of ecotypic speciation in Anopheles gambiae. Proc Natl Acad Sci U S A 2008, 105:2940-2945.

22. Coluzzi M: Spatial distribution of chromosomal inversions and speciation in Anopheline mosquitoes. Prog Clin Biol Res 1982, 96:143-153.

23. Diabate A, Dao A, Yaro AS, Adamou A, Gonzalez R, Manoukis NC, Traore SF, Gwadz RW, Lehmann T: Spatial swarm segregation and reproductive isolation between the molecular forms of Anopheles gambiae. Proc Biol Sci 2009, 276:4215-4222.

24. Charlwood JD, Jones MDR: Mating behaviour in the mosquito, Anopheles gambiae s.l. I. Close range and contact behaviour. Physiol Entomol 1979, 4:111-120.

25. Pennetier C, Warren B, Dabire KR, Russell IJ, Gibson G: "Singing on the wing" as a mechanism for species recognition in the malarial mosquito Anopheles gambiae. Curr Biol 2010, 20:131-136.

26. Sanford MR, Demirci B, Marsden CD, Lee Y, Cornel AJ, Lanzaro GC: Morphological differentiation may mediate mate-choice between incipient species of Anopheles gambiae s.s. PLoS One 2011, 6:e27920.

27. Costantini C, Ayala D, Guelbeogo WM, Pombi M, Some CY, Bassole $\mathbb{H}_{\text {, }}$ Ose K, Fotsing JM, Sagnon N, Fontenille D, et al: Living at the edge: biogeographic patterns of habitat segregation conform to speciation by niche expansion in Anopheles gambiae. BMC Ecol 2009, 9:16.

28. Edillo FE, Tripet F, Toure YT, Lanzaro GC, Dolo G, Taylor CE: Water quality and immatures of the $\mathrm{M}$ and $\mathrm{S}$ forms of Anopheles gambiae s.s. and An. arabiensis in a Malian village. Malar J 2006, 5:35.

29. Gimonneau G, Pombi M, Choisy M, Morand S, Dabire RK, Simard F: Larval habitat segregation between the molecular forms of the mosquito Anopheles gambiae in a rice field area of Burkina Faso, West Africa. Med Vet Entomol 2012, 26:9-17.

30. Lehmann T, Diabate A: The molecular forms of Anopheles gambiae: a phenotypic perspective. Infect Genet Evol 2008, 8:737-746.

31. Marsden CD, Lee Y, Nieman CC, Sanford MR, Dinis J, Martins C, Rodrigues A, Cornel AJ, Lanzaro GC: Asymmetric introgression between the $\mathrm{M}$ and $\mathrm{S}$ forms of the malaria vector, Anopheles gambiae, maintains divergence despite extensive hybridization. Mol Ecol 2011, 20:4983-4994.

32. Caputo B, Santolamazza F, Vicente JL, Nwakanma DC, Jawara M, Palsson K, Jaenson T, White BJ, Mancini E, Petrarca V, Conway DJ, Besansky NJ, Pinto J, della Torre A: The "far-west" of Anopheles gambiae molecular forms. PLoS One 2011, 6:e16415.

33. Coluzzi M, Sabatini A, Petrarca V, Di Deco MA: Chromosomal differentiation and adaptation to human environments in the Anopheles gambiae complex. Trans R Soc Trop Med Hyg 1979, 73:483-497.

34. Touré YT, Petrarca V, Traoré SF, Coulibaly A, Maiga HM, Sankare O, Sow M, Di Deco MA, Coluzzi M: The distribution and inversion polymorphism of chromosomally recognized taxa of the Anopheles gambiae complex in Mali, West Africa. Parassitologia 1998, 40:477-511.

35. Diabate A, Dabire RK, Kim EH, Dalton R, Millogo N, Baldet T, Simard F, Gimnig JE, Hawley WA, Lehmann T: Larval development of the molecular forms of Anopheles gambiae (Diptera: Culicidae) in different habitats: a transplantation experiment. J Med Entomol 2005, 42:548-553.

36. Tene Fossog B, Kopya E, Ndo C, Menze-Djantio B, Costantini C, Njiokou F, Awono-Ambene P, Antonio-Nkondjio C: Water quality and Anopheles gambiae larval tolerance to pyrethroids in the cities of Douala and Yaounde (Cameroon). J Trop Med 2012, 2012:429817.

37. Bigoga JD, Ndangoh DN, Awono-Ambene PH, Patchoke S, Fondjo E, Leke RG: Pyrethroid resistance in Anopheles gambiae from the rubber cultivated area of Niete, South Region of Cameroon. Acta Trop 2012 124:210-214.

38. Slotman MA, Tripet F, Cornel AJ, Meneses CR, Lee $Y$, Reimer $L$, Thiemann TC, Fondjo E, Fofana A, Traoré SF, GC L: Evidence for subdivision within the M molecular form of Anopheles gambiae. Mol Ecol 2007, 16:639-649.

39. Kaiser $P$, Seawright J, Birky B: Chromosome polymorphism in natural populations of Anopheles quadrimaculatus Say species A and B. Genome 1988, 30:138-146.

40. Olvera O, Powell J, De La Rosa M, Salceda V, Gaso M, Guzman J, Anderson W, Levine L: Population genetics of Mexican Drosophila VI. cytogenetic aspects of the inversion polymorphism in Drosophila pseudoobscura. Evolution 1979, 33(1):381-395.

41. Krimbas CB: Powell. JR: Drosophila inversion polymorphism. CRC Press I LIC 1992.

42. Craddock EM, Johnson WE: Genetic variation in Hawaiian Drosophila. V. Chromosomal and allozymic diversity in Drosophila silvestris and its homosequential species. Evolution 1979, 33(1):137-155.

43. Dobzhansky T: Adaptive changes induced by natural selection in wild populations of Drosophila. Evolution 1947, 1:1-16.

44. Gray EM, Rocca KA, Costantini C, Besansky NJ: Inversion 2La is associated with enhanced desiccation resistance in Anopheles gambiae. Malar J 2009, 8:215.

45. Fouet C, Gray E, Besansky NJ, Costantini C: Adaptation to aridity in the malaria mosquito Anopheles gambiae: chromosomal inversion polymorphism and body size influence resistance to desiccation. PLoS One 2012, 7:e34841

46. Cheng C, White BJ, Kamdem C, Mockaitis K, Costantini C, Hahn MW Besansky NJ: Ecological genomics of Anopheles gambiae along a latitudinal cline: a population-resequencing approach. Genetics 2012, 190:1417-1432.

47. Diabate A, Dabire RK, Heidenberger K, Crawford J, Lamp WO, Culler LE Lehmann T: Evidence for divergent selection between the molecular forms of Anopheles gambiae: role of predation. BMC Evol Biol 2008, 8:5

48. Scott JA, Brogdon WG, Collins FH: Identification of single specimens of the Anopheles gambiae complex by the polymerase chain reaction. Am J Trop Med Hyg 1993, 49:520-529. 
49. Favia G, Lanfrancotti A, Spanos L, Siden-Kiamos I, Louis C: Molecular characterization of ribosomal DNA polymorphisms discriminating among chromosomal forms of Anopheles gambiae s.s. Insect Mol Biol 2001, 10:19-23.

50. Santolamazza F, Mancini E, Simard F, Qi Y, Tu Z, della Torre A: Insertion polymorphisms of SINE200 retrotransposons within speciation islands of Anopheles gambiae molecular forms. Malar J 2008, 7:163.

51. White BJ, Santolamazza F, Kamau L, Pombi M, Grushko O, Mouline K, Brengues C, Guelbeogo W, Coulibaly M, Kayondo JK, et al: Molecular karyotyping of the 2La inversion in Anopheles gambiae. Am J Trop Med Hyg 2007, 76:334-339.

52. Obbard DJ, Linton YM, Jiggins FM, Yan G, Little TJ: Population genetics of Plasmodium resistance genes in Anopheles gambiae: no evidence for strong selection. Mol Ecol 2007, 16:3497-3510.

53. Ng'habi KR, Horton A, Knols BGJ, Lanzaro GC: A new robust diagnostic polymerase chain reaction (PCR) for determining the mating status of female Anopheles gambiae mosquitoes. Am J Trop Med Hyg 2007, 77:293-293

54. SPSS I: SPSS Graduate Pack 16.0 for Windows. Chicago: 16.0 .1 edition; 2007.

55. Coluzzi M, Sabatini A, Della Torre A, Di Deco MA, Petrarca V: A polytene chromosome analysis of the Anopheles gambiae species complex. Science 2002, 298:1415-1418.

56. Hanna-Instruments Canada I: Conductivity and TDS Meters. Hanna Instruments Canada, Inc.

57. Simard F, Ayala D, Kamdem GC, Pombi M, Etouna J, Ose K, Fotsing JM Fontenille D, Besansky NJ, Costantini C: Ecological niche partitioning between Anopheles gambiae molecular forms in Cameroon: the ecological side of speciation. BMC Ecol 2009, 9:17.

58. Paaijmans KP, Heusinkveld BG, Jacobs AF: A simplified model to predict diurnal water temperature dynamics in a shallow tropical water pool. Int J Biometeorol 2008, 52:797-803.

59. Kirby MJ, Lindsay SW: Effect of temperature and inter-specific competition on the development and survival of Anopheles gambiae sensu stricto and An. arabiensis larvae. Acta Trop 2009, 109:118-123.

60. Mohammed A, Chadee DD: Effects of different temperature regimens on the development of Aedes aegypti (L.) (Diptera: Culicidae) mosquitoes. Acta Trop 2011, 119:38-43.

61. Okech BA, Gouagna LC, Yan G, Githure Jl, Beier JC: Larval habitats of Anopheles gambiae s.s. (Diptera: Culicidae) influences vector competence to Plasmodium falciparum parasites. Malar J 2007, 6:50

62. Kamdem C, Fossog BT, Simard F, Etouna J, Ndo C, Kengne P, Bousses P, Etoa FX, Awono-Ambene P, Fontenille D, Antonio-Nkondjio C, Besansky NJ, Costantini C: Anthropogenic habitat disturbance and ecological divergence between incipient species of the malaria mosquito Anopheles gambiae. PLoS One 2012, 7:e39453.

doi:10.1186/1475-2875-12-225

Cite this article as: Sanford et al:: A preliminary investigation of the relationship between water quality and Anopheles gambiae larval habitats in western Cameroon. Malaria Journal 2013 12:225.

\section{Submit your next manuscript to BioMed Central and take full advantage of:}

- Convenient online submission

- Thorough peer review

- No space constraints or color figure charges

- Immediate publication on acceptance

- Inclusion in PubMed, CAS, Scopus and Google Scholar

- Research which is freely available for redistribution

Submit your manuscript at www.biomedcentral.com/submit
Ciomed Central 